\title{
Deoxyribonucleic acid polymorphism of the apoprotein AI-CIII-AIV gene cluster and coronary heart disease in non-insulin-dependent diabetes
}

\begin{abstract}
The prevalence of an uncommon allelic variant (S2) of the apoprotein AI-CIII-AIV gene cluster was determined in noninsulin-dependent diabetics with or without evidence of coronary heart disease and in controls. Frequencies of the S2 allele were $14 \%$ for diabetics with coronary heart disease compared with $2 \%$ for non-diabetics with no clinical evidence of occlusive vascular disease. No subject with the S2 allele was detected among a further group of matched diabetics without clinical features of macrovascular disease.

The results suggest that a genetic component contributes to the susceptibility to coronary heart disease in non-insulindependent diabetics. Whether the observed deoxyribonucleic acid variant is aetiological for atherosclerosis or in linkage disequilibrium with other atherogenic loci on chromosome 11 remains to be clarified.
\end{abstract}

\section{Introduction}

Recombinant deoxyribonucleic acid (DNA) probes have been used to identify DNA variants of the apoprotein AI-CIII-AIV gene
Non-insulin-dependent diabetics have roughly twice the incidence of coronary heart disease compared with age matched non-diabetic subjects. ${ }^{5}$ Though the prevalence of various environmental risk factors for atherogenesis in diabetes has been intensively studied, ${ }^{6}$ the role of inherited factors has been largely ignored. We therefore decided to study the distribution of the apoprotein CIII genotype in a group of carefully defined non-insulin-dependent diabetics with evidence of coronary heart disease to see whether similar genetic determinants occur in this important subgroup of patients with arterial disease. Recognising major genes concerned in the pathogenesis of atherosclerotic arterial disease would considerably expand our understanding of this process and, by identifying susceptible people at an early age, may allow the introduction of preventive measures. ${ }^{\text {? }}$

\section{Patients and methods}

Table I gives the clinical details of the 102 white subjects studied. All were recruited from either the Whittington or St Bartholomew's Hospital, and all diabetics were classified as non-insulin-dependent (type II) based on World Health Organisation criteria. ${ }^{8}$ Of the 47 patients who presented with evidence of coronary heart disease before the age of 60,35 were survivors of

\begin{tabular}{|c|c|c|c|c|c|c|c|c|}
\hline Study group & $\begin{array}{l}\text { No } \\
\text { in } \\
\text { group }\end{array}$ & $\begin{array}{l}\text { No } \\
\text { of } \\
\text { men }\end{array}$ & $\begin{array}{l}\text { Mean } \\
\text { age } \\
\text { (years) } \\
\text { (SD) }\end{array}$ & $\begin{array}{l}\text { No }(\%) \text { with } \\
\text { ideal body } \\
\text { mass } \\
(>120 \%)\end{array}$ & $\begin{array}{l}\text { No }(\%) \\
\text { with } \\
\text { hypertension }\end{array}$ & $\begin{array}{c}\text { Mean } \\
\text { duration of } \\
\text { diabetes } \\
\text { (years)(SD) }\end{array}$ & $\begin{array}{c}\text { Mean } \\
\text { serum } \\
\text { cholesterol } \\
(\mathrm{mmol} / \mathrm{l})(\mathrm{SD})\end{array}$ & $\begin{array}{c}\text { Mean } \\
\text { serum } \\
\text { triglyceride } \\
(\mathrm{mmol} / \mathrm{l})(\mathrm{SD})\end{array}$ \\
\hline $\begin{array}{l}\text { Non-insulin-dependent diabetics with coronary heart disease } \\
\text { Non-insulin-dependent diabetics with no clinical evidence of heart disease } \\
\text { Non-diabetic controls }\end{array}$ & $\begin{array}{l}47 \\
20 \\
35\end{array}$ & $\begin{array}{l}26 \\
8 \\
18\end{array}$ & $\begin{array}{l}59 \cdot 4(8 \cdot 42) \\
61 \cdot 0(3 \cdot 80) \\
54 \cdot 2(1 \cdot 27)\end{array}$ & $\begin{array}{r}20(43) \\
8(40) \\
7(20)\end{array}$ & $\begin{array}{r}10(21) \\
3(15) \\
5(14)\end{array}$ & $\begin{array}{r}9 \cdot 4(6 \cdot 20) \\
11 \cdot 2(5 \cdot 30)\end{array}$ & $\begin{array}{l}7 \cdot 1(1 \cdot 02)^{\star} \\
6 \cdot 9(1 \cdot 21) \\
6 \cdot 2(0 \cdot 61)\end{array}$ & $\begin{array}{l}2 \cdot 4(1 \cdot 01) \dagger \\
1.6(0 \cdot 37) \\
1 \cdot 4(0 \cdot 41)\end{array}$ \\
\hline
\end{tabular}

*Compared with non-diabetic controls $\mathrm{p}<0.01$ (unpaired $t$ test)

tCompared with both other groups $\mathrm{p}<0.01$ (unpaired $t$ test).

loci that associate with coronary atherosclerosis and may represent potential genetic markers for this common disorder. In a group of young survivors of myocardial infarction $21 \%$ possessed an uncommon genotype of the apoprotein CIII gene compared with only $4 \%$ of normotriglyceridaemic controls. ${ }^{1}$ Other studies of normolipaemic patients with angiographically defined obstructive coronary artery disease found a variant genotype frequency of between $18 \%$ and $24 \% .{ }^{23}$ One variant allele (S2) is identified by an additional cleavage site for the restriction enzyme Sst 1 and hybridisation with either an apoprotein AI or CIII gene probe. ${ }^{4}$

Medical Professorial Unit, St Bartholomew's Hospital, London EC1

R C TREMBATH, BSC, MRCP, research registrar

D J B THOMAS, MD, MRCP, senior registrar

D J GALTON, MD, FRCP, consultant physician

Academic Department of Diabetes and Endocrinology, Whittington Hospital, London

T J HENDRA, BSC, MRCP, research registrar

J S YUDKIN, MD, MRCP, consultant physician

Correspondence to: Dr Galton. myocardial infarction, based on clinical history, typical electrocardiograms, and cardiac enzyme changes. The remaining 12 patients had been investigated by coronary arteriography because of persistent chest pain and were found to have severe occlusive coronary artery stenosis requiring bypass surgery. A second group of 20 non-insulin-dependent diabetics with no clinical evidence of vascular disease or hypertriglyceridaemia at the time of study were also genotyped. All gave a negative response to an angina questionnaire, ${ }^{9}$ none had a history of coronary heart disease, and all had palpable peripheral pulses and normal resting electrocardiograms. A group of 35 age matched non-diabetic patients attending the medical outpatient department (rheumatology and chest clinics) served as further controls.

DNA analysis-DNA was isolated from leucocytes in $10 \mathrm{ml}$ venous blood as described by Kunkel $e t$ al. ${ }^{10}$ Analysis of apoprotein CIII genotypes was performed as described. ${ }^{1}$

Statistical analysis-The association of gene related polymorphisms with diabetic coronary heart disease was analysed by a $2 \times 2$ contingency table comparing the polymorphism genotype with the disease group. A $\chi^{2}$ test of significance was then applied.

\section{Results}

After digestion with the restriction endonuclease Sst 1 three gene related fragments were visualised by hybridisation with an apoprotein AI probe 
(figure). The 5.7 kilobase pair $(\mathrm{kbp})$ fragment was invariant and the polymorphism was characterised by the presence of either a $4.2 \mathrm{kbp}$ fragment (S1 allele) or a $3.2 \mathrm{kbp}$ fragment (S2 allele). Subjects were genotyped SIS1 if they possessed only the 5.7 and $4.2 \mathrm{kbp}$ fragments and $\mathrm{S} 1 \mathrm{~S} 2$ if they possessed all three.

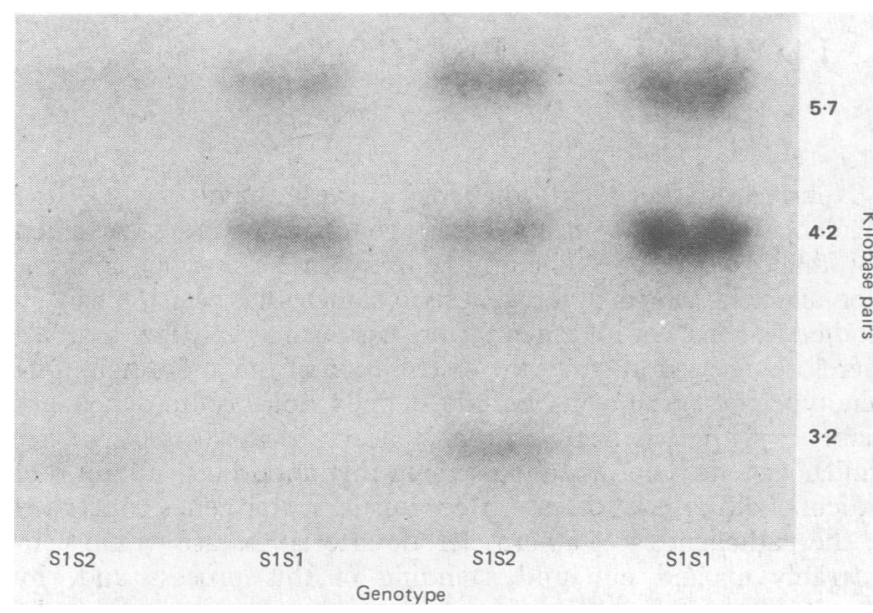

Autoradiograph of genomic DNA digested with restriction enzyme Sst 1 and hybridised with phosphorus labelled AI gene probe.

There was a significant increase in the prevalence of the S2 allele among the non-insulin-dependent diabetic group with coronary heart disease compared with the non-diabetic controls (table II). The frequency of the S2 allele was significantly higher among the normolipaemic non-insulindependent diabetics with evidence of coronary heart disease compared with both normolipaemic non-diabetics $(p<0.01)$ and normolipaemic diabetics without evidence of vascular complications $(p<0.001)$. Frequencies of the apoprotein CIII allele were similar for both the diabetic survivors of myocardial infarction and those patients with angiographically defined coronary artery disease (data not shown). Of the diabetics with coronary heart disease, $20(43 \%)$ had fasting hypertriglyceridaemia at the time of study and six of these possessed the $\mathrm{S} 2$ allele.

TABLE II-Apoprotein CIII genotypes and frequencies of alleles

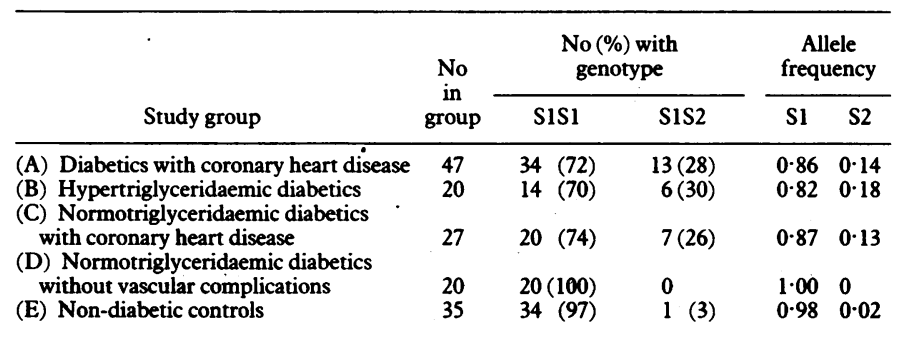

Allele frequencies: (A) $v$ (E) $\mathrm{p}<0.01$; (A) $v$ (D) $\mathrm{p}<0.001$; (B) $v$ (E) $\mathrm{p}<0.001$; (C) $v$ (D) $\mathrm{p}<0.001 ;(\mathrm{C}) v(\mathrm{E}) \mathrm{p}<0.01$ ( $\chi^{2}$ test).

\section{Discussion}

We have studied a variant of the apoprotein AI-CIII-AIV gene cluster which associates with coronary heart disease in non-insulindependent diabetics and provides evidence for a genetic component in the aetiology of this important long term diabetic complication. At present it is not clear whether polymorphisms at this gene cluster are aetiological for atherosclerosis. DNA variation at this locus might predispose to coronary atherosclerosis by altering plasma lipid concentrations. Possession of the S2 allele, however, does not appear to influence concentrations of circulating serum apoprotein AI or apoprotein CIII. ${ }^{4}$ Alternatively the observed association with coronary heart disease in non-insulin-dependent diabetics may arise from linkage disequilibrium with other atherogenic loci on chromosome 11.

Three further points emerge from our study. The results from the non-insulin-dependent diabetics with coronary heart disease who were normolipaemic at the time of study suggest that the observed increase in frequency of the S2 allele was independent of any association with diabetic hypertriglyceridaemia. No significant differences in the frequencies of the $\mathrm{S} 2$ allele were observed between normotriglyceridaemic and hypertriglyceridaemic diabetics with clinical evidence of vascular disease. Nevertheless, of all subjects with diabetes and coronary heart disease, 20 (43\%) had fasting hypertriglyceridaemia at the time of study and six of these patients were heterozygous for the S2 allele. This supports previous data on the increased frequency of the S2 allele in diabetic hypertriglyceridaemia." Finally, no significant difference in frequencies of alleles was found between normotriglyceridaemic diabetics without clinical evidence of vascular disease and the non-diabetic controls. Hence there appears to be no disease association between diabetes alone and this DNA variant of the apoprotein CIII gene.

Though our observations provide evidence for at least one common genetic determinant for coronary heart disease in both diabetics and non-diabetics, we cannot exclude the possibility of differences in the contribution of other loci to the predisposition to coronary heart disease in diabetes.

We thank the cardiothoracic surgeons and Dr M Green of St Bartholomew's Hospital for allowing us to study patients under their care. We acknowledge the support of the Wellcome Trust (RCT) and the British Diabetic Association (DJG). TJH is a Novo research fellow.

\section{References}

1 Ferns GAA, Stocks J, Ritchie C, Galton DJ. Genetic polymorphisms of apolipoprotein CIII and insulin in survivors of myocardial infarction. Lancet $1985 ; \mathrm{ii}: 300-3$.

2 Rees A, Caplin J, Jowett NI, et al. DNA polymorphisms of the Apo CIII and insulin genes and atherosclerosis. Atherosclerosis 1985;58:269-75.

3 Ordovas JM, Schaefer EJ, Salem D, et al. Apolipoprotein AI gene polymorphism associates with premature coronary artery disease and familial hypoalphalipoproteinemia. $N$ Engl f Med 1986;314:671-7.

4 Rees A, Stocks J, Sharpe CR, et al. Deoxyribonucleic acid polymorphism in the apolipoprotein AI-CIII gene cluster: association with hypertriglyceridemia. F Clin Invest 1985;76:1090-5.

5 Jarrett RJ. Type 2 (non-insulin-dependent) diabetes mellitus and coronary heart diseasechicken, egg or neither? Diabetologia 1984;26:99-102.

6 Kannel WB, McGee DL. Diabetes and cardiovascular risk factors. Circulation 1979;59:8-13.

7 Weatherall DJ. The new genetics and clinical practice. 2nd ed. London: Oxford University Press, 1985.

8 WHO Expert Committee on Diabetes Mellitus. Second report. WHO Tech Rep Ser 1980; No 646.

9 Rose G, Blackburn H. Cardiovascular survey methods. Geneva: World Health Organisation, 1968. (WHO monograph series No 56.)

10 Kunkel LM, Smith KD, Boyer SH. Analysis of human Y chromosome specific reiterated DNA in chromosome variants. Proc Natl Acad Sci USA 1977;74:1245-9.

11 Jowett NI, Rees A, Williams LG, et al. Insulin and apolipoprotein A-I/CIII gene polymorphisms relating to hypertriglyceridaemia and diabetes mellitus. Diabetologia 1984;27:180-3.

(Accepted 2 April 1987)

\section{YEARS AGO}

Attention has been called by a contemporary to a system of fraud which has been practised in connection with the working of the new French law which enjoins that all packages containing butter substitutes shall be specially marked with words denoting the admixture, the term usually employed being graisse alimentaire. This law has led to the discovery that a large amount of the "guaranteed" French butter is either butterine or an admixture. Manufacturers in France who are now compelled by French law to brand these goods do so, but large quantities are marked in addition "guaranteed pure butter," and when the goods arrive in this country the words graisse alimentaire are removed. One of the southern railway companies has, it is said, actually fixed a tariff for the commission of this fraud, and other companies allow it to be perpetrated by the owner while the goods are in transit. Such frauds should be summarily suppressed, and, if necessary, the law should be strengthened in order that the perpetrators may be severely punished. (British Medical Fournal 1887;ii:369.) 